\title{
First Cohort of Physicians in Maintenance of Certification for Family Physicians (MC-FP) Completes Second Stage in Strong Numbers
}

The American Board of Family Medicine (ABFM) is pleased to announce that, as of March 1, 2010, almost 8500 of the Diplomates who were certified or recertified in 2003 successfully met the deadline of completing their stage one and stage two requirements for Maintenance of Certification for Family Physicians (MC-FP) and have been granted a 3-year extension of their current certificate, creating a 10-year certificate. The 2003 Diplomates were the first cohort to begin the MC-FP and to be eligible to extend their 7-year certificate to a $10-$ year certificate. Of those Diplomates who were certified or recertified in 2006 and who began their MC-FP in 2007, close to 8000 have successfully completed stage one and are currently in stage two.

The first 3-year stage of the MC-FP process includes completing either 3 part II modules (SelfAssessment Modules [SAMs]), or 2 part II modules and one part IV module (Performance in Practice Module [PPM] or approved alternate). Stage two requirements include 2 part II modules (SAMs) and one part IV module (PPM or approved alternate). These requirements may be completed anytime before the deadline. The ABFM website will immediately indicate the 3-year certificate extension when the Diplomates complete stage two requirements.
The Diplomates who were certified or recertified in 2007 and who began their MC-FP in 2008 must complete their stage one requirements by December 31, 2010. To date, close to 3800 of the 2008 cohort have completed one or more of the SAMs and are on track to complete their stage one requirements by the end of the year.

Diplomates who were certified or recertified in 2008 have until December 31, 2011 to complete the stage one requirements. Diplomates who were certified or recertified in 2009 may now begin working on the MC-FP modules at their convenience. Stage one requirements for the 2009 cohort are due by December 31, 2012.

To help all Diplomates keep track of their progress on the MC-FP, the ABFM has updated its website to reflect the 7-year or 10-year track, whichever was chosen by the Diplomate. All Diplomates are encouraged to visit the ABFM website (www.theabfm.org) and $\log$ on to the physician's portfolio section. The ABFM website now publicly reports the MC-FP status as part of Diplomate certification status.

Jane Ireland

American Board of Family Medicine 